\title{
Homoeopathy: past, present and future
}

\author{
E. Ernst \\ Department of Complementary Medicine, Postgraduate Medical School, University of Exeter, 25 Victoria Park Road, Exeter EX2 4NT
}

\section{Introduction}

Since Samuel Hahnemann (1755-1843) published his 'like cures like' (simile similibus curentur) principle 200 years ago [1], homoeopathy has repeatedly been in and out of favour and fashion [2]. In spite of the fact that its rationale flies in the face of science and its clinical efficacy remains unconvincing [3], UK sales of homoeopathic remedies are increasing by $20 \%$ annually [4]. The following communication will summarize the criticism homoeopathy has received during its existence, outline the present situation and try to determine what the future may bring.

\section{Historical criticism}

From its very beginning, homoeopathy received fierce criticism. In his book: 'Anti-Organon oder das Irrige der Hahnemannschen Lehre im Organon der Heilkunst' (AntiOrganon or the errors of Hahnemann's teachings in the organon) [5], J.C.H. Heinroth for instance stated that medicine was misguided to accept from Hahnemann 'much that would not have stood the test of a sharp mind'. Others called homoeopathy 'the highest triumph of ignorance and mysticism' [6] and 'a public scandal' [7]. Oliver Wendel Holmes analysed Hahnemann's three basic assumptions (the 'like cures like' principle, the theory about infinitesimal dilutions and the origin of all disease) in some detail and concluded, "when one man claims to have established these three independent truths, which are about as remote from each other as the discovery of the law of gravitation, the invention of printing, and that of the mariner's compass, unless the facts in their favour are overwhelming and unanimous, the question naturally arises, is not this man deceiving himself, or trying to deceive others?' [8]. Many physicians agreed: 'either Hahnemann is right, in which case our science and the basis of our thinking is nonsense, or he is wrong, in which case this teaching is nonsense. There is no third option' [9]. The Encyclopaedia Britannica of 1891 summarized the orthodox view of that time: 'Hahnemann's errors were great. His doctrine of specifics was highly retrograde ... He led his followers far out of the track of sound views of disease ... But ... he had the great merit of disturbing and discrediting indefensible modes of practice' [10].

\section{Criticism within homoeopathy}

Hahnemann, called 'the Messiah of Medicine' by his disciples [10], considered homoeopathy to be the 'only law consonant to nature' and anyone disagreeing with it was 'an apostate and a traitor' [11]. Nevertheless several contemporary homoeopaths did dare to rebel. In 1837, the German homoeopath Paul Wolf published his 18 theses which entailed a departure both from high dilutions and Hahnemann's psora theory [12]. Forty years later, the vice president of the British Homoeopathic Society wrote in the Lancet: '... the views expressed by Hahnemann are often extravagant and incorrect ... some diseases are best treated by similars and some by contraries ... [13]. At the end of the 19th century, homoeopathy had 'no scientific recognition' and was 'universally condemned' [10]. Yet even critics (now and then) admit that homoeopathy has its merits: it led to the gradual disappearance of some overtly harmful treatments of its time. Homoeopaths were also pioneering modern trial designs, albeit with regrettably little impact on mainstream medicine [14].

\section{The present}

Recently George Vithoulkas, an internationally acclaimed homoeopath, was awarded the 'Alternative Nobel Prize', the Right Livelihood Award, for his outstanding contribution to the revival of homoeopathic knowledge [15]. UK Sales of remedies increase every year by around $20 \%$ [4]. As part of the general 'boom' in complementary medicine, more and more patients turn to homoeopathy [16]. Exact figures are hard to come by, but in a survey of almost 4000 asthma patients $12 \%$ had tried homoeopathy [17]. The climate has changed, and even the Cochrane collaboration is now involved in meta-analyses of homoeopathic trials [18].

Perhaps not surprisingly, the 'opposition' has once again aligned, and their arguments have become focused on several recurring themes. The most elementary one is that highly diluted homoeopathic remedies are in every possible way indistinguishable from pure diluents. This was highlighted by the 'Benveniste affaire'. Benveniste and his group had apparently shown that ultra-high dilutions can have biological activity [19]. Subsequently a team of 'quack busters' visited Benveniste's laboratory and concluded that his experiments were flawed [20]. Later, a group of independent scientists was unable to replicate Benveniste's results [21].

The clinical efficacy of homoeopathy continues to be questioned [e.g. 22]. Systematic reviews and meta-analyses of controlled clinical trials invariably suggest that the effects of homoeopathic treatments are more than a placebo response. Yet numerous methodological shortcomings prevent more definitive conclusions [3, 23-25]. Nonetheless, today's homoeopaths seem convinced that the proof of their methods' effectiveness has been demonstrated. The 'opposition', on the other hand, remains uniquely unconvinced.

Other critics have questioned the prevalent notion that homoeopathy is inherently and entirely risk-free. Reports of adverse reactions to homoeopathic remedies do exist [e.g. $26,27]$, the use of heavy metals might represent a problem [28], and there are important indirect risks, for example homoeopaths' opposition to immunisation [29]. Even if homoeopathic remedies were totally safe, not all homoeopaths necessarily are. Others again point out that homoeopathy as a unified school of thought simply does not exist; there are 'as many homoeopathies are there are homoeopaths' 
[30]. Finally opponents stress that homoeopathy has all the qualities of a sect [31]; a group of German professors recently called homoeopathy 'a media-hyped superstition' [cited in 32].

At least one country has taken the drastic step of banning outright homoeopathic remedies [33]. In the US and Europe, the regulatory authorities are more liberal and allow registration of highly diluted homoeopathic remedies without evidence of safety or efficacy [34].

In terms of research, some conclude that more and better investigation ought to be done in order to determine whether homoeopathic remedies are more than placebos [e.g. 3, 22, 23, 25]. Others argue that this would be a 'great waste of time' [31, 35]. George Vithoulkas (see above) stubbornly counters: 'If the world's medical authorities still choose to ignore Hahnemann's beneficial discoveries ... they will be accused by succeeding generations of criminal negligence and shortsightedness' [15].

\section{The future}

If homoeopathy is to survive, it must become evidencebased. The fact that homoeopathy is utterly implausible is disturbing, it should not, however, deter us from investigating whether or not it works clinically [37]. Many homoeopaths claim that the randomized clinical trial is not applicable to a treatment as individualized and subtle as homoeopathy [38]. This argument has been shown to be wrong simply by the fact that good randomized trials exist which homoeopaths unanimously acclaim [e.g. 39]. A valid criticism lies in the fact that even the best such studies were conducted by enthusiasts in the absence of impartial, close monitoring. What we require therefore, is not another series of hundreds of trials which inevitably would leave sceptics sceptical. Much rather, a small set of randomized trials is needed, which are planned, executed, monitored, analysed and published by both knowledgable proponents and informed critics - trials which are sufficiently definitive and rigorous to convince both camps no matter what the result may turn out to be.

Recently the European Union set up a truly balanced panel of experts (believers, disbelievers and impartial scientists) in an attempt to solve some of the existing controversies. The group met regularly for 2 years and produced a sizeable document [40]. By no means does it solve all the problems - in fact it asks more questions than it answers - but it represents an honest attempt to advance the issue free of emotions. This, in my view, is the way to proceed. Homoeopathy, one might speculate, will be a science or it will not be.

\section{Conclusions}

Two hundred years of arguments and counter-arguments are more than enough. The most pressing question, is homoeopathy clinically more effective than (or even clinically distinguishable from) placebo', needs to be answered conclusively. We do not need yet another two or three hundred non-definitive studies, but two or three convincing, methodologically rigorous trials conducted and overseen by a balanced team of investigators. In the light of homoeopathy's present popularity, it would be nothing less than unethical [41] and against the best interest of our patients [16] not to take up this challenge.

\section{References}

1 Hahnemann S. Versuch über ein neues Prinzip zur Auffindung der Heilkräfte der Arzneisubstanzen. J Prakt Arzneykunde u Wundarzneykunst 1796; 2: 391-439.

2 Ernst E, Kaptchuk TJ. Homoeopathy revisited. Arch Intern Med 1996; 156: 2162-2164.

3 Kleijnen J, Knipschild P, ter Riet G. Clinical trials of homoeopathy. Br Med J 1991; 302: 316-332.

4 Fasihi A. Complementary medicine Vol I, Medicinal remedies. FT Pharmaceuticals and Healthcare Publications. London, 1996.

5 Heinroth J Chr A. Anti-Organon. Leipzig, 1825.

6 Cited in: Giese Ch, Gellert M. Zur Geschichte der Veterinärhomöopathie in Deutschland. Berl Münch Tierärztl Wschr 1995; 108: 305-312.

7 Diepholz G. Einige Bemerkungen über die Kritik der Zooiasis, besonders aber der gesamten Homöopathie. Magazin für gesamte Thierheilkunde 1836; 8: 299.

8 Holmes OW. Homoeopathy and its kindred delusions, 1842. republished In Examining holistic medicine. Stalker D, Gylmour C (eds). Buffalo: Prometheus Books, 1985.

9 Jürgensen Th. Die wissenschaftliche Heilkunde und ihre Widersacher. Volkmanns Sammlung Klinischer Vorträge 1876; 106: 879-916.

10 Encyclopaedia Britannica. Homoeopathy 1891; 12: 126-129.

11 Hahnemann S. Organon der Heilkunst. 5th Edition, Dresden: Arnold, 1833.

12 Wolf P. Achtzehn Thesen für Freunde und Feinde der Homöopatik. Arch homöop Heilkunde 1837; 16: 1.

13 Wyld D. Homoeopathy. Lancet 2 June 1877.

14 Kaptchuk TJ. Early use of blind assessment in a homoeopathic scientific experiment. Br Homoeop J 1997; 86: 49-50.

15 Scott-Moncrieff. The Editor's Notebook Simile, April 1997 p.1 and 11-12.

16 Ernst E. Patients' Perception of Complementary Therapies. Forsch Komplementärmed 1995; 2: 326-329.

17 Ernst E. unpublished data.

18 Linde K, Jobst K. Homoeopathy for the treatment of asthma bronchiale. The Cochrane Library 1997; issue 2, p. 1.

19 Devenas E, Beauvais F, Amara J, et al. Human basophil degranulation triggered by very dilute antiserum against $1 \mathrm{gE}$. Nature 1988; 333: 316-318.

20 Maddox J, Randi J, Stewaart WW. 'High dilution' experiments a delusion. Nature 1988; 333: 287-290.

21 Hirst SJ, Hayes NA, Burridge J, Pearce FL, Foreman JC. Human basephil degranulation is not triggered by very dilute antiserum against human IgE. Nature 1993; 366: 525-527.

22 Ernst E. Is homoeopathy a placebo? Br J Clin Pharmacol 1990; 30: 173-174.

23 Homoeopathic Medicine Research Group: Overviews of data from homoeopathic medicine trials. European Commission, 1996.

24 Barnes J, Resch KL, Ernst E. unpublished data.

25 Linde K, Clausius N, Ramirez G, et al. Overviews and metaanalysis of controlled clinical trials in homoeopathy. In Homoeopathy a critical appraisal, eds Ernst E, Hahn. London: Butterworth, 1997.

26 Ernst E. The safety of homoeopathy. Br Homoeop J 1995; 84: 193-194.

27 Abbot NC, White AR, Ernst E. Complementary Medicine. Nature 1996; 381: 361.

28 Forth W. Potentiell toxische Schwermetalle als 
Therapeutikum in der Homöopathie. Dtsche Ärzteblatt 1996; 93: C1653-164.

29 White AR, Ernst E. Homeopathy and immunization. $\mathrm{Br}$ J Gen Pract 1995; 25: 629-630.

30 Prokop O, Hopff W. Erklärung zur Homöopathie. Dtsch Apotheker Zeitung 1992; 132: 1630-1631.

31 Jarvis W. Homeopathy, a position statement by the National Council Against Health Fraud. Sceptic 1994; 3: 50-57.

32 Meyer FP. Vorlesungen über Homöopathie. Jena: G Fischer, 1996.

33 Menczel E. Outlawing homeopathy in Israel. Am J HealthPharm 1995; 52: 2471.

34 Baker EA. European regulations covering homoeopathic medicines. Forsch Komplementärmed 1996; 3: 311.

35 Vandenbroucke JP. Theory and practice. How do they relate to each other, and why is a practice like homeopathy theoretically unacceptable? In Kritik der medizinischen Vernunft, eds Schmidt JG, Steele RG. Kirchheim, Mainz 1994.
36 Walach H, Righetti M. Homoeopathy-foundations, research and strategies of evaluation. Wien Klin Wochenschr 1996; 108: 654-653.

37 Berkowitz CD. Homoeopathy, keeping an open mind. Lancet 1994; 344: 701-702.

38 European Committee for Homoeopathy communication of 16/17 June 1994.

39 Reilly D, Taylor MA, Beattie NGM, et al. Is evidence for homoeopathy reproducible? Lancet 1994, 344: 1601-1606.

40 Available from European Commision on request (contact address: Dr G N Fracchia, European Commission, DG XII Medical Research, 8 Square de Meeûs, 1049 Brussels, Belgium.

41 Ernst E. The ethics of complementary medicine. J Med Ethics 1996; 22: 197-198.

(Received 4 March 1997, accepted 2 July 1997) 